trato perfeito, que compensa o negócio causal que não tiver seguido a forma estipulada. O Código Civil chega a um resultado semelhante, mas percorre um caminho bem diferente na sua resolução do caso concreto, e não menciona, por exemplo, o princípio da separação de negócios (Abstraktionsprinzip). A transferência de direitos reais é efetuada através de contratos. A perfeição destes exige necessariamente o acordo entre as partes, e este por sua vez torna-se perfeito somente após a exe- cução do ato material (na maioria das vezes a transmissão da propriedade). Desta forma, o direito português não diferencia entre negócio obrigacional e dispositivo. ${ }^{137}$ Para a proteção de ferceiros de boa-fé, examina-se o direito adquirido separadamente do primeiro negócio, entretanto, isto só ocorre em casos restritos e previstos por lei. ${ }^{138}$ Este direito adquirido de terceiros que merecem proteção parece ser a alma gêmea do negócio abstrato, que é, contudo, desconhecido do diploma português.

\title{
New Trends in European Community Law
}

\author{
Serhand Laule \\ Professor da Disciplina de Harmonização tributária no Direito Comunitário \\ Europeu do Instituto Europa da Universidade do Saarland
}

\section{Reviewing European Business Law: the Difficulty of Global Awareness and in Selection of the Most Relevant}

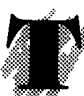

o design business strategies unde European Community law, one mus constantly and keenly be aware of new developments. It is only one aspect to cope with the acribic and ever growing out put of the European Community legislator - the legendary Brussels "papermill". What a businessperson also needs to know is: How do the European bureaucrats understand and instrumentalize legislative texts in a climate that is so heavily influenced by politics and lobbying as Brussels? That mean that business persons need to be informed about what the European Commission is thinking and how the European courts in Luxembourg will possibly react. This will not only help them to solve problems, bu also prevent problems from developing.

Community competition and international trade law is expanding at such a rate that more and more law is developing in increasingly less and less time. To illustrate, supplements to authoritative works on EC competition law - such as the infamous Bellamy and Child on European antitrust law - are now as long as the first editions of said books. The quantity of decisions and other important texts keeps multiplying, especially decisions by the European Court of First Instance. This poses the formidable problem of weeding the irrelevant out from the relevant, and the relevant from the very relevant. The material selected for this essay was chosen particularly with an eye to the potential needs of Japanese business exporters. With this in mind, I have done my best to include most important and up-to-date issues in European antitrust and international trade law.

\section{Antitrust}

\section{A. Generalities}

The European Community is one of limited powers; these powers fall short of those of a state (see Articles 3b (1) and 4 
(1), second sentence of the EC Treaty and Article E of the Treaty on European Community). The limited powers principle must be respected in both the internal action and the international action of the Community. ${ }^{1}$

In the area of antitrust, the limited powers principle means that Community institutions must confine their measures to those which are necessary to achieve undistorted and fair competition in the internal market (see Article 3b (3) in conjunction with Article 3 lit. g and the Fourth Recital of the EC Treaty). Undistorted and fair competition in turn must inure to the benefit of the consumer alone - and not to the benefit of industry.

\section{Approaches of the Community}

Despite the limited powers principle, in practice, the ambition of Community action is to widen Community power with the aspiration to turn the Community into a Quasi-state, and to reduce Member State power accordingly.

One means to enlarge the Community powers, and especially those of the Commission, are the antitrust provisions set out in Articles 85 et seq. of the EC Treaty and most notably Article 85: Article 85 (1)

Opinion $2 / 94$ of the ECJ of March 28, 1996 (Accession by the
and Fundamental Freedoms) [1996] ECR I-1759, point 24.

and Fundamental Freedoms) [1996] ECR I-1759, point 24.

2. See, e.g., Case 7/93 Langnese-Iglo v. Commission [1995] ECR II-1533, point 178: "The Commission's exclusive power ... to grant an exemption under Article 85 (3) of the Treaty necessarily involves complex evaluations on economic matters. Ajudicial review of such evaluations must take account of their nature by confining itself to an examination of the relevance of the facts and of the legal inferences drawn by the Commission from them. The judicial review must therefore in the first place be carried out in respect of the reasons given for the decisions, which must set out the facts and considerations on which the said evaluations are based. ... It is in the light of those principles, as expounded in the case law, that it is necessary to verify whether the decision is based on a materially incorrect appreciation of the facts or is vitiated by errors of law or manifest errors of assessment ..."

3. See, generally, van der Woude, Decentralization, National Authorities and National Courts, speech given at the IBC Conference on European Antitust, 1996, p. 14; Gerrit Schohe/Mark Hoenike, Die Rechtsprechung von EuGH und EuG zu staatlichen Beihiffen on European Antitrust, 1996, p. 14; Gerrit Schohe/Mark Hoenike, Die Rechtsprechung von EuGH und EuG zu staatilichen Beihiten
in den Jahren 1996 und 1997; EuZW Europäische Zeitschrift für Wirtschaftsrecht 1997, p. 742; see in particular for this trend in the

Revista da Faculdade de Direito da UFRGS, v. 15, 1998 ties to the arrangement to restructure, modify, or abandon this arrangement as the Commission deems best. This paves the way from the protection of "undistorted and fair competition", to which the Commission is confined under the limited powers principle, to politically motivated shaping of the industry and its structures by the Commission.

Legal scholars, for example Valentine $\mathrm{Korah}^{4}$, have over and over insisted that a competition-restricting practice in many cases cannot be affirmed simply on the basis of allegation, conjecture or remote possibilities. ${ }^{5}$ Such an affirmation, in their opinion, requires most often market analysis. Also, some "rule of reason" should be acknowledged. Under such a rule, Article 85 (1) would be inapplicable where the arrangement can be justified whilst taking full account of "fair and undistorted competition". Where market analysis or the rule of reason shows that the arrangement has no appreciable effect on competition or trade between the Member States, the Commission cannot simply rush to Article 85 (3) to restructure industrial arrangements.

The leading case in which the ECJ insisted on market analysis is Delimitis. ${ }^{6}$
However, this case does not seem to have essentially changed the Commission's power-oriented policy. To a considerable extent, what is allowed or forbidden continues to depend more on politics and skillful lobbying than on law. Parties, especially from outside the European Community, should be aware of this when seeking antitrust approval by the Commission. One example may be the establishment in the European Community of a selective distribution network. In a combined legal and lobbying effort, the parties must give their project some European spin to win the Commission's political sympathy and, ultimately, approval.

The Commission's antitrust ap. proach is indifferent from the one taken by the Community Courts. The next section will deal with the fact that the Community courts tend towards a more legalistic approach.

\section{Approaches of the \\ European Court}

The Commission's strife for antitrust power in certain cases clashed with the approach of the Community courts to Article 85. commission's antitrust policy in the banking and insurance sector: Luc Gyselen, EU Antitrust Law in the Area of Financial Services
- Capita Selecta for the Cautious Shaping of a Policy, in: International Antitrust Law, and Policy 1996, Fordham Corp. L Just (Barry - Capita Selecta for the Cautious Shaping of a Policy, in: Intern
Hawck, ed. 1996), p. 337 et seq., 344, 356, 367 et seq., 385.

4. See e.g. Valentine Korah, Warwick A. Rothnie, Exclusive Distribution and the EEC Competition Rules, Chapter 7.2.; see also e.g. Luc Gyselen, supra note 3, p. 392.

5. As authority for the contention that such relaxed tests are insufficient see Article 3.6 of the WTO Agreement on Implementation of Article VI of the General Agreement on Tariffs and Trade 1994. Under this provision, a determination of material injury (in the Article $V$ of the General Agreement on Tarifits and Trade 1994 . Under this provision, a determination of material injury (in the sense of anti-dumping law) shall be based on facts and not merely on allegation, conjecture or remote possibility. This rule seems
sound in all market-related assessments, and one should always rely on it to encourage the Community institutions and Courts to sound in all market-related assessments, and

6. Case C-234/85 Delimitis v. Henninger [1991] ECR I-935, points 14 et seq.

7. See, generally, Schohe, European Lobbying and the Law: Disinterested Twins?, Public Affairs newsletter, July / August 1996, Vol. 2 No. 10, p. 6 et seq. 
Traditionally, the Commission has analyzed agreements that may restrict competition in terms of whether the agreement limits the commercial freedom of any of the contracting parties and whether the agreement has negative effects on the position of competitors or consumers. This test is referred to as the freedom of action theory. ${ }^{8}$ The Commission generally limits itself to an assessment of the status of the agreement in question in relation to Article 85 (1). The Commission's approach is rather abstract and fails to look at the actual results of the restrictive behaviour in light of the market conditions. Since this brings the case to the Commission's almost unreviewable power to grant exemptions under $\mathrm{Ar}$ ticle 85 (3), as mentioned above, it can be assumed that the Commission is led by the consideration to retain as much power as possible

The approach of the Community courts to Article 85 contrasts with that of

the Commission in that the investigation whether an agreement restricts competition takes place in two stages. ${ }^{9}$ First, the Community courts examine whether the arrangement under consideration does not have as its objective the restriction of competition, i.e. whether it restricts competition per se. Such would be the case with "deadly sins" like price fixing ${ }^{10}$. Second, where there is no restriction of competition per se, the Courts assess the effect that the agreement may have on competition as the ECJ did in Delimitis. ${ }^{11}$ This effect is to be determined on the basis of the general criterion of how competition would have developed in the absence of the arrangement. $^{12}$ The Community Courts have consistently supported the economic analysis of the impact of the arrangement on the market in question. ${ }^{13}$ For example, the ECJ has held that compatibility with Article $85(1)$ of the non-competition

8. See for example Deacon "Vertical Restraints under EU Competition Law: New Directions" (1995) speech delivered at the Fordham Corporate Law Institute: Hawk "System Failure: Vertical Restraints and EC Competition Law" (1995) 32 CML Rev. at 973. Illustrative in this respect is the Commission's 23rd Report on Competition Policy 1993, point 212, in which the Commission states that the exclusive nature of a contractual ralationship between a producer and a distributor is viewed as restricting competition, since it limits the parties' freedom of action on the teritory covered " This test primarily relo to the restriction of the freedom of the limits he parties' feedom of action on the lerilory covered." This lest primarly relales to the restriction of the freedom of the contracting parties. Its application has particularly been criticized by, for example, Van Houtte "A Standard of Reason in EEC Antitrust Law: Some Comments on the Application of Parts 1 and 3 of Article 85" (1982) Northwestem Joumal of Intermational Law \& Business 497 and V. Korah An Introductory Guide to EC Competition Law and Practice, Sweet \& Maxwell, 5th edn, 1994, ch 14.2.2, who hold that the test is intrinsically wrong since any commercial transaction ipso facto restricts a party's freedom to enter
into a similar transaction.

See, for example, Case $56 / 65$

Henniger Bräu [1991] ECR I-935.

10. This test requires an investigation of the objectives of the agreement and purpose considered in the economic context in which it operates, see, for example, Cases 29-30/83, Zinc Producers v. Commission (1984) ECR 1679.

11. Supra footnote 5 .

12. See, for example, Société Technique Minière v. Maschinenbau Ulm, supra footnote 5 and Case T-61/89 Dansk Pelsdyravier v. Commission [1992] ECR II-1931. In order to fall under Articles 85 or 86 of the EC Treaty the agreement must also have an "appreciable effect" on competition and on interstate trade; for details, see below at $D$.

13. Fiona Murray and Jacquelyn MacLennan, "The Future for Selective Distribution Systems: The CFI Judgments on Luxury Perfume and the Commission Green Paper on Vertical Restraints", European Competition Law Review, Volume 18 issue 4, June 1997 at 232.

Revista da Faculdade de Direito da UFRGS, v. 15, 1998 clauses cannot be assessed in abstract terms ${ }^{14}$ but depends on the economic conditions in the relevant market. ${ }^{15}$

In addition to this, the case law of the Community courts shows an implied tendency to adopt the American antitrust concept of a "rule of reason". The supreme goal of the competition rules is undistorted competition in the internal market (Article 3 lit. $g$ of the EC Treaty; for the concept of the internal market see Article 7a (2) of the EC Treaty), i.e. public trade barriers within the European Community which by and by have been abolished must be prevented from being replaced by arrangements between private parties. Thus; as an example, the "rule of reason" approach may exclude the application of Article 85 (1) where, based on market analysis, restrictions to competition do not directly impede trade between Member States or where, on balance, the arrangement can be seen as pro-competitive overall. ${ }^{16}$ Three examples can be given:

Firstly, the ECJ ruled in Delimitis that Article 85(1) should not be applied to all contractual restrictions of competition rather the impact of said restrictions should be evaluated under Article 85(1) and not Article 85(3). ${ }^{17}$

Secondly, the ECJ has identified cer tain restrictions that fall outside of Article

14. See for example, infra. Langnese v. Commission, Doctrine of complex economic evaluation.

15. Case C-250/92 Gottrup Klim, judgment of 15 December 1994

16. R. Whish, Competition Law, Butterworths, 3rd edn, 1993, at 205-10.

17. Supra footnote 5 Delimitis.

18. [1994] ECR I-5641 but see also the restrictive jurisprudence by Advocate General Lenz in Case C-415/93 Bosman [1995] ECR I 4921 at points 266 to 269 of his opinion.

19. See Case 56/65 Société Technique Minière v. Maschinenbau Ulm; Case 258/78 Nungesser v. Commission (1982) ECR 2015; Case 2621/81 Coditel v. Cine-Vog Films (1982) ECR 3381/81.
85(1) because they are necessary for the performance of a particular type of transaction ("ancillary restrictions"). Thus, in Case C-250/92 Gottrup-Klim v Dansk Landbrugs Grovvareselskab Amba ${ }^{18}$, the Court of Justice held that the rules of a Danish agricultural cooperative purchasing organisation that prevented members from joining competing co-operatives, may have an adverse effect on competition. However, the Court further said that this will not constitute a violation of Article 85 (1) if the prohibition goes no further than is necessary to ensure that the co-operative functions properly and maintains its purchasing power in relation to producers.

Thirdly, the ECJ has in some vertical agreements cases held a rule of reason that in order to induce a licensee or distributor to enter the market, some encouragement in the form of territorial protection is needed and thus not prohibited under Article $85(1) .{ }^{19}$

\section{B. Procedural Rights; Access to the Commission's Files}

Clearly, access to the Commission's file, i.e. sufficient knowledge about the subject matter of the Commission's administrative procedures, is necessary to enable the parties concerned (e.g. the addressees of a statement of objections under Article 2 (1) of Regulation 99163 on the Hearings provided for in Article 19 (1) and 19 (2) of

Revista da Faculdade de Direito da UFRGS, v. 15, 1998 
Regulation $17^{20}$ ) to fully exercise their right to be heard and to defend themselves properly. In this respect, Community procedural law seems to be far away form reaching the point of development of national procedural law. However, there are positive developments in the jurisprudence. In the Soda ash cases of Solvay and ICI ${ }^{21}$ the CFI ruled in essence that the principle of "equality of arms" required that the undertakings against whom a Commission investigation is directed must have knowledge of the file that is equal to that of the Commission. In consequence of these judgments, the Commission decided to simplify its procedures concerning access to the file. It adopted a Notice on the Internal Rules of Procedure for Processing Requests for Access to the File in Cases Pursuant to Article 85 and 86 of the EC Treaty, Articles 65 and 66 of the ECSC Treaty and Council Regulation No. 4064/89.22

The Notice deals primarily with the scope and limits of access to the file and the practical procedures for access. It should be noted, however, that the internal rules of procedure relate only to the rights of firms being investigated for a pos. sible violation and not to the rights of third parties and complainants. The firms in question have access to essentially all documents except those containing business or professional secrets of other undertakings, internal Commission documents and other

\section{OJ 1963, 2268}

21. Decided in parallel: Cases T-30/91 Solvay v. Commission [1995] ECR II-1775; Case T-36/91 ICl v. Commission [1995] ECR II1847; Case T-37/91 ICl v. Commission [1995] ECR II-1901.

22. OJ C 23, 23 January 1997.

23. See Article 214 of the EC Treaty, Article 20 of Regulation 17 (basic code of procedure in European antitrust matters), OJ 1962, 131/204 and OJ 1959-62, 87; Case T-7/89 Hercules Chemicals v. Commission [1991] ECR II-1711. petition-sensitive arrangement, or competitors of parties seeking approval of state aid by the Commission. ${ }^{24}$ As a rule, third party rights to be heard are less developed than in most Member States. ${ }^{25}$

In European Community Law the right to be heard is in principle established in all proceedings initiated against a person which could result in a measure adversely affecting that person. This fundamental principle is guaranteed even in the absence of written law. ${ }^{26}$ Carrying the right to be heard one step further, the ECJ in the British American Tobacco-R.J. Reynolds ${ }^{27}$ and Lisrestal cases recognized the right of interested third parties, not just respondents; to be heard prior to the adoption of a decision capable of adversely affecting them. ${ }^{28}$ This is tempered with the fact that third parties' procedural rights are not as far reaching as the right to a fair hearing of the companies which are the object of the Commission's investigation, and the limits of such rights are reached when third parties begin to in terfere with those companies' rights to a fair hearing.
If a third party wishes to exercise its right to be heard, it must be directly concerned with the matter in question. ${ }^{29}$

Concerning state aid clearance under the preliminary procedure under Article 93 (3) of the EC Treaty, the CFI stated in a dictum: Where the Commission intends taking a measure adversely affecting a third party, but the Commission does not hear that third party in respect to information on which the measure is to be based, then the Commission is under an obligation to examine ex officio the objections which the third party would certainly have raised had it been heard. ${ }^{30}$ It is submitted that this dictum may lend itself to general application in the whole of European competition law. Third parties should be advised that if they wish to exercise their right to be heard in an efficient way they should cooperate with the Commission, e.g. by voluntarily providing information requested by the Commission. For example, in Pleuger Worthington, another state aid case, the ECJ held that should the Commission by way of a decision request information and it is not
24. This latter category of cases cannot be further examined at this stage. But see Schohe, Rivals in a state, Airline Business August 1996, p. 42 et seq.

25. Intra. See generally Case 142/84 and 156/84 British American Tobacco Company Litd and R.J. Reynolds Industries, Inc. v. Commission [1987] ECR 4487. Also see Sinochem case in Anti-Circumvention Rules section.

26. Case C-135/92, Fiskano v. Commission, [1994] ECR I-2885; Case C-32/95 P Commission v Lisretal and others [1996] ECR I. 5373, point 21; Case C-301/87 France v Commission [1990] ECR 1-307, point 29; Joined Cases C $48 / 90$ and C 66/90, Netherlands and others v. Commission, [1992] ECR I-565, point 44.

27. Case 142/84 and 156/84 British American Tobacco Company Ltd and R.J. Reynolds Industries, Inc. v. Commission [1987] ECR 4487. Complainants must be given the opportunity to defend their legitimate interests during the administrative proceedings and the Commission must consider all the matters of fact and of law that they bring to its attention.

28. Case C-32/95P Commission v. Lisrestal [1996] ECR I 5373

29. See, Lisrestal, id. at points 22 et seq

30. Case T-95/94, Sytravalv. Commission: [1995] ECR II-2651 point 66; see for this case: Gerrit Schohe/Mark Hoenike, supra note 3, p. 742; Bernhard Schloh/Mark Hoenike, Die Anforderungsfrist bei der Konkurrentenklage im Beihifenrecht nach Art. 173 EGV, EuzW Europäische Zeitschrift für Wirtschaftsrecht 1997, p. 398 et seq. 
provided with it, the Commission is not obliged to seek it elsewhere, but may proceed upon the facts available. ${ }^{31}$

It is obvious that third parties must be sufficiently informed about the subject matter of the proceedings in advance so that they can exercise their right to be heard in an efficient way. This intersects with the aforementioned problem of access to the Commission's file. Unfortunately, this basic right seems to be at an "embryonic stage" in Community law. The strongest authority that we can find in support of advance information of third parties is the opinion of Advocate General Warner in Case 113/ 77 NTN Toyo Bearing Company v. Council ("ballbearings"). He said:32

"It is a fundamental principle of Community law that, before any individual measure is taken, of such nature as directly to affect the interests of a particular person, that person has a right to be heard by the responsible authority; and it is part and parcel of that principle that, in order to enable him effectively to exercise that right, the person concermed is entitled to be informed of the facts and considerations on the basis of which the authority is minded to act. That principle ... applies regardless of whether there is a specific legislative text requiring its application."

Similarly, in Al Jubail, the ECJ declared an anti-dumping regulation to be void on the basis that the Community in-

stitutions had failed to provide the plaintiffs with the necessary information in or der for them to exercise their procedural rights in an adequate manner. ${ }^{33}$ There is no legal reason to treat third parties in antitrust cases differently from parties in antidumping cases like in Al Jubail.

Again, however, it should be noted that European Community law, on the one hand and European Community daily practice, on the other, may substantially differ. Despite legal arguments, in practice third parties are faced with the difficulty of obtaining a hearing and, as a prerequisite for such a hearing, sufficient information on the subject matter of the Commission procedure. Thus, for example, in KSB / Goulds / Lowara / ITT ${ }^{34}$, third parties opposed an exemption under Article 85 (3) from the ban on competition-restricting practices. In that attempt, the Commission was requested to send them copies of the briefs submitted by the applicants for the exemption, with business secrets to be deleted. All they received were copies of a few selected briefs; in addition, the Commission had deleted so many parts of these briefs that no meaningful response was possible.

Another third party problem is posed by the informal hearings between the Commission and the parties to a competitionsensitive arrangement. Such information hearings, as a matter of practice, most of-

31. Joined Cases C-324/90 and C-342/90 Federal Republic of Germany and Pleuger Worthington GmbH v. Commission [1994] ECR 1-1173, points 27 and 28 .

33. Case 49/88 Al Jubail Fertilizer v. Council [1991] I-3187, point 18.

34. Commission Decision of December 12, 1990 relating to a proceeding under Article 85 of the Treaty in Case ND IV. 32.363 - KSB / Goulds / Lowara / ITT, OJL $19 / 25$.

Revista da Faculdade de Direito da UFRGS, v. 15, 1998
32. [1979] ECR 1185 at 1261. ten take place prior to formal proceedings before the Commission. During the informal stage, the Commission will bend over backwards to ensure that it gets as wide an input as possible from third parties. However, it adamantly refuses third parties, at this stage, access to any of the information collected from other sources. This is a very serious shortcoming if one considers that the Commission often forms a preliminary opinion on the case already on the basis of the informal talks.

In addition, two recent developments regarding access to information should be briefly noted:

Firstly, on the basis of Community legislation ("secondary Community Law"), the Community courts have begun developing a general right of information for eve. ryone as regards internal documents of the Community institutions (for example preparatory papers for closed-door legislation by the Council). In a nutshell, under this recent jurisprudence, the institution concerned has to weigh, on a case-by-case basis, its interests in confidentiality against the private person's interest in obtaining the information sought. ${ }^{35}$

Secondly, pursuant to the recent Postbank judgment ${ }^{36}$, national courts, based on the duty of sincere cooperation enshrined in Article 5 of the Treaty, may ask the Com- mission for information about competition cases pending before the latter. Parties may use this as a possibility of indirectly obtaining information from the Commission. Article 20 of Regulation 17 (the Basic Antitrust Procedural Code), which normally protects business secrets against disclosure, is not applicable in this instance. Subject to necessary precautions to be taken by the Commission, it is for the national courts to protect the rights of defence of the enterprises concerned and their business secrets and other confidential information. ${ }^{37}$

In any case, third parties regularly should be advised to exercise their rights in the administrative procedure before the Commission to the fullest. First, such procedural engagement may help them to establish standing pursuant to Article 173 (5) of the Treaty, if they should wish to challenge the ensuing Commission decision before the Community courts. Second, inmade it clear that judges do not consider their court procedure to be a repetition of the Commission procedure. Therefore, even if there is no rule to this effect, a party's influence before the Community courts appreciates substantially if the plaintiff has vigorously defended its interests before the Commission and exhausted each legal remedy available before that institution. ${ }^{38}$ formal talks with European judges have

35. See Judgment of March 5, 1997, Case T-105/95, WWF v. Commission, not yet officially published; Case T-194/94, Carvel and Guardian Newspapers Ltd. v. Council, [1995] ECR II-2767; Case C-58/94 Netherlands v. Commission [1996] ECR I-2186, point 34.

36. Case T-353/94 Postbank v. Commission [1996] ECR, II-923; see further Joined Cases C-319/93, C-40/94 and C-224/94 Dijkstra and others [1995] ECR, I-4471, point 34 and Case C-234/89 Delimitis [1991] ECR I-935, point 53. See also Commission Notice between national courts and the Commission in applying Articles 85 and 86 of the EEC Treaty, OJ 1993 C 39/6.

37. See Postbank, id. at points 72 and 73 and 90.

38. See, for relatively recent example, Case T-161/94 Sinochem Heilongjiang v. Council, [1996] ECR I-695, points 47 to 49 (standing on account of active participation).

Revista da Faculdade de Direito da UFRGS, v. 15, 1998 


\section{Giving Evidence Against Accomplices ("King's Evidence") and the} Commission's New Leniency

On July 10, 1996, the European Commission adopted a Notice on the nonimposition or reduction of fines in carte cases. ${ }^{39}$ It applies to hard core infringements of the antitrust rules such as price-fixing fixation of sales or production quotas, mar ket sharing, ("chacun chez soi") or import or export bans: By reducing or waiving the fine which normally would have imposed, the Commission hopes to provide ample incentive to break down the barriers of se crecy surrounding cartels and encourage firms from engaging in anti-competitive practices to supply evidence. It should be recalled that antitrust fines can reach up to $10 \%$ of an undertakings yearly turnover. ${ }^{40}$ While new, the notice conforms to the Commission's established practice of taking cooperation into account. The Case Cartonboard ${ }^{41}$ illustrates that prompt and effective remedial action and co-operation with the Commission may result in substantial mitigation of the fine. A $66 \%$ reduc tion in fines was given to an undertaking which handed over documents and to a leader in the cartel who provided details regarding various committees. A 33\% reduction was granted to those firms who did not contest the factual allegations.

Most recently, in the infamous Lysine case, there was an instance of whistle blowing (cooperation between one of the designers of a price-fixing arrangement and US investigation services) in a situation involving alleged price fixing by a US subsidiary of a globally active Japanese firm that resulted in all but three defendants settling and in record breaking fines of $\$ 100 \mathrm{mil}$ lion. Attractive as the Commission's leniency policy may be, this policy is nevertheless a delicate one. Where an undertaking wishes to take advantage of the Notice, it should retain specialist advice rather than speak with Commission unpreparedly.

In addition to fixing, the Lysine case alerted also the other side of the Atlantic, i.e. the Commission. This raised the issue of extraterritorial application of European antitrust law which is dealt with in the next section.

39. OJ C 207, July 18, 1996. This notice is closely modeled on the "Corporate Leniency Policy" issued by the US Department of Justice in August 1993.

40. See Article 15 of Regulation 17 .

41. Cases T-308/94 Cascades SA and others v. Commission, C-64/94R Descow Scales v Council[1994] - I-867 (a.k.a. the Cartonboard decisions) [1995] ECR II-265; see in particular the treatment of Stora in Cartonboard, [1994] 5 CMLR 547 ("very substantia reduction in the fine" for spontaneous admission and provision of detailed evidence that assisted the investigation: $\$ 171$ ); OJ 1994 L 243/1 [1994] 5 CMLR 547, on appeal Cases T-295/94, etc. see also, Case T-156/94R Aristrain v. Commission [1994] II ECR 717 (partial suspension of the fine) (pending); see generally, concerning agreements on selling prices and conditions: Joined Cases T-134/94, T-136/94, T-137/94, T-138/94, T-141/94, T-145/94, T-147/94, T- 148/94, T-151/94, T-156/94 and T-157/94 NMH Stah/werke GmbH and Others v. Commission (a.k.a.Steel beams decisions) [1996] ECR II-0537; OJ 1994 L 116/1 [1994] 5 CML R 353 on appeal Cases T-137/94, etc. (pending) and Joined Cases T-10/92, T-11/92, T-12/92 and T-15/92 Cimenteries CBR SA and Others $v$. Commission (ak a the Coment decisions) [1992] ECR II-2667 Od 1994 L 343/1 [1995] 4 VMLT 327, on Cases T-25/95, etc. (pending).

Revista da Faculdade de Direito da UFRGS, v. 15, 1998

C. Extraterritorial Application of EC-Competition Law: The ECJ's territoriality principle v. the Commission's effects doctrine

With the global opening of markets ("globalization") especially under the auspices of the World Trade Organization (WTO) anti-competitive actions in one market may now affect other markets in other regions of the world. More than any other development, globalization has raised the issue of whose market's antitrust authority should have jurisdiction over the case. Should there be concurring jurisdictions with the risk of diverging opinions? $O r$, in the alternative, should "positive comity" be given - so that one antitrust authority may defer to the opinion of another antitrust authority, for example on the grounds that the latter is better situated to investigate the case or that the impact of the case on the latter authority's market is greater? Where no "positive comity" is given, can trade wars or diplomatic conflicts over diverging antitrust opinions be avoided on the basis of bilateral or multilateral agreements or within the framework of such international dispute settlement bodies as provided for by the WTO? These issues are so important that the WTO during its $1996 \mathrm{Sin}$ gapore conference established a working group on cooperation in competition mat- ters with a report due out in 1998. The current European viewpoint on these issues is as follows:

In Woodpulp II ${ }^{42}$ the ECJ decided that the place where the competition-restrictive agreement was to be implemented was decisive for the jurisdiction of the EU institutions. The Court also said that the Community could apply European Community competition rules to undertakings outside the European Community under the principle of territoriality, a universally recognized principle in public international law. ${ }^{43}$

On the other hand, the Commission relies on the effects doctrine when applying antitrust law to undertakings outside of the EU. In Woodpulp, ${ }^{44}$ the Commission asserted that the Community had jurisdiction over undertakings which implement a concerted practice that directly, intentionally and appreciably affects competition within the Community and trade between its members. It was sufficient that the undertakings either imported into or used agents or sales offices within the EU.

The Commission reiterated this line of reasoning in Gencor/Lonrho. ${ }^{45}$ Gencor Ltd. of South Africa and Lonrho plc of the United Kingdom intended to acquire joint control of Impala Platinum Holdings Limited, a South African platinum mining and refinery company. The Commission de-

42. Joined Cases 89, 104, 114, 116, 117 and 125 to $129 / 85$ Ahlström Osakeyhtiö and Others v. Commission ECR (1988) 5223, 5246; the Commission decision in the matter is universally cited as "Woodpulp", while the judgment is known as "Woodpulp II".

43. See, e.g. Alfred Verdross and Bruno Simma, Universelles Völkerrecht - Theorie und Praxis, $\$ 1166$.

44. Commission decision of 19 December 1984 relating to a proceeding under Article 85 of the EEC Treaty Case No. IV/29/.725 Woodpulp, OJ L 85/1, March 261985.

45. Commission decision of 24 April 1996 declaring a concentration to be incompatible with the Common Market and the functioning of the EEA Agreement, Case No. IVIM.619 - Gencor/Lonrio, OJ L 11/30, 14.01.1997. 
clared the transaction incompatible with the common market based on the determination that the operation would create a medium term dominant position in the platinum market reducing competition on the worldwide platinum market. The Commission did not deem it important that Impala Platinum Holdings Limited was situated outside the EU and that the Community market obtained most of its platinum from Russia. Rather, the Commission held that the platinum market was a world market with prices set at the world market level. Thus, anti-competitive effects of this operation such as higher prices on all platinum sold in the world would be felt inside the EU. ${ }^{46}$

Clearly, the effects doctrine of the Commission is much wider in scope than the territoriality principle used by the Court. In contrast to the territoriality principle, the effects doctrine is not a universally accepted principle of public international law. Consequently, with its effect doctrine as a base, the Commission could face problems under international law when applying European antirust law to enterprises or conduct outside of its accepted realm of jurisdiction. This difficulty has not deterred the Commission, as illustrated in by one of the most prominent cases of this year: the recent and

dramatic intervention by the European Commission in the US Boeing-McDonnell Douglas merger. ${ }^{47}$ It is astonishing that in its 33 page decision concerning the Boeing McDonnelDouglas merger ${ }^{48}$, the Commission did not say a single word about its assumption of jurisdiction over the case. The question arises whether this blatant omission was due to oversight, lack of arguments, or simply political arrogance.

The merger between Boeing and McDonnell Douglas took the cooperation agreement between the EC and the US competition authorities ${ }^{49}$ to its limits. The situation turned into a fierce conflict between the European Commission and the US resulting in middle of the night phone calls from US President Clinton to heads of state. For obvious reasons, the US did not appreciate the European Commission assuming jurisdiction in its affairs and still bears a grudge. In addition, as the merger was not a day to day matter, the college of all Commissioners and not Competition Commissioner van Miert had to decide. However, according to one of the French Commissioners in an interview, the Commissioners were given the necessary information so late that they could not study the files before the decision was taken. While the Commission will assert that it

46. Ibid. at paragraph 206.

47. On merger-preventing strategies see generally, Tefft W. Smith and Hillard M. Sterling, Challenging Competitors' Mergers: A Real Strategic Option, Antitrust Law Journal vol. 65 [1996]. The threat of litigation is addressed as a real and potentially poweriul Strategic Option, Antitrust Law Journal vol. 65 [1996]. The threat of litigation is addressed as a real and potentially powertul
strategic option to disrupt a rival's proposed acquisition or merger regardless of the government's decision to mount a challenge or not.

48. This far, the Commission decision on the Boeing / McDonnelDouglas merger has not yet been published.

49. Agreement between the Government of the United States of America and the Commission of the European Communities regarding the application of their competition laws. OJ Nr. L 95/45, 27.04.1995. See Commission Report to the Council and the European Parliament on the Application of the Agreement between the Government of the United States of America and the Commission of the European Communities regarding the application of their competition law. KOM(96) 479 . decided without succumbing to political pressure, the market place perception is that it held out until the last moment for a concession from Boeing to save face. As one director in the Commission put it: "No agreement can deal with the situation where people come to different conclusions on the same facts. We are entitled to our view and they are entitled to theirs. ${ }^{150}$ In light of statements such as these, one is in cluded to wonder whether the European Commission, beyond the Boeing case, wanted to stake a power claim among the world's big trading blocks. ${ }^{51}$

It has also been reported that the European Commission was threatering KLM and its US partner Northwest with daily fines if they continued to refuse to provide further details concerning their alliance. One can only question whether or not the European Commission is entitled, under public international law, to fine Northwest. ${ }^{52}$

The Boeing case was not an isolated incident, but only reflects a problem that arises over and over in daily practice. Two examples of my current cases will underline this. One of them involves an exclu- sive purchasing agreement between a Japanese and US firm. The agreement explicitly states that it does not apply to the Commission is likely to use its effects doctrine claims jurisdiction as European sales will suffer as a consequence of the aforementioned agreement. Another of our recent cases involved the question of whether the Commission could impose fines on a related but separate firm here in Europe based on the findings of the investigation in the US concerning a US firm's alleged price fixing scheme. These are thought-provoking examples of the breadth of the effects doctrine and in contrast, the principle which would not have lent legal support to the Commission's objective.

Under these circumstances bilateral agreements, like the US-EC agreement on competition matters, are becoming more and more important. The Agreement is aimed at preventing conflicts in the enforcement of the European and US competition laws. ${ }^{53} 54$ Terms have been laid out for detailed consultation on cases and issues of common interest. Each party agrees European Community. Nonetheless, the restrictiveness of the Court's territoriality

50. Jonathan Faull, quoted in (1997) European Counsel, Vol. II № 8, p. 15

51. For a US-American view expressing understanding of the Commission's assumption of concurrent jurisdiction in the Boeing case see Joel J. Klein, in his address of October 16, 1997 to the Fordham Annual Conference on International Law and Policy (Anticpating the Millenium: International Antitrust Enforcement at the End of the Twentieth Century), at p. 10 et seq (not yet published).

52. Het Financieele Dagblad (Dutch Newspaper) of January 16, 1997.

53. It provides for:

firstly, notification of enforcement activities which may affect important interests of the other party; secondly, an exchange o information on general matters relating to the application of the parties' competition laws, thirdly, the duty to take account in enforcement activities of the other party's important interests, and, fourthly, a positive comity procedure under which either party may request the other party to initiate appropriate enforcement activities in respect of anti-competitive activities occurring within the latter's territory and affecting the former's important interests.

54. Jean-Yves Art and Dirk Van Liedekeerke, Developments in EC Competition Law in 1995: an Overview, CML Rev. Vol. 33, No. 4 August 1996 at $773-74$ 

plicate the other's antitrust laws. Provisions governing the transfer of confidential information are also included. ${ }^{55}$ The main practical issue remains that unless the parties are willing to waive confidentiality provisions and to cooperate in a joint investigation, confidentiality laws limit the amount of information that can be exchanged. Communication of confidential information by the Commission seems to be a practical impossibility as Article 214 of the EC Treaty prevents the Commission from doing so. ${ }^{56}$ Though judged a success, this Agreement is a rather toothless tiger. ${ }^{57}$

There now is a proposed EC-US Agreement on the application of positive comity principles in the enforcement of competition law. As of yet, there is no understanding on how to solve conflicts of jurisdiction between the US and the European Community in a competition matter. Likewise, there is no arrangement concerning which of the parties has the final say should there be a disagreement. Similarly, there is no reference made to which arbitrating body (i.e. the International Court in the Hague or the WTO), if any, is to setthe disagreements. All of this may change, as the US authorities are threatening to take the Boeing case to the WTO. to notify the other of matters that may im-

It should be added that the US Department of Justice and the Federal Trade Commission issued updated "Antitrust Enforcement Guidelines for International Operation." ${ }^{8}$ These explain that in appropriate cases, US agencies may take enforcement action against anti-competitive conduct that restrains US exports wherever it occurs. ${ }^{59}$ This jurisdiction is based on unilateral action by the US agencies and a narrow definition of international comity. Just like the Commission's unilateral interference in the Boeing-McDonnell Douglas merger, the US guidelines are a tool for trade policy. They are highly controversial. The preceding comments concentrated on the US and Europe. However, as the Lysine case makes clear, the Japanese industry may easily become entangled in international antitrust conflicts. With that in mind, it seems alarming that between trading blocks as large as Japan and the Community, there is no bilateral legal framework for the resolution of potential jurisdictional conflicts in antitrust matters.

\section{Appreciable effect}

The doctrine of " appreciable effect" is an additional means to narrow the overly broad wording of Article 85 (1) of the EC Treaty. It is one of four means whereby an

55. Ronan Harty and Joel Cohen, From Notification to Approval: USA European Council October 1997 at 128.

56. Reported by John Ratilff, Major Events in EC Competition Law, IBC Conference November 1995. The obligations on confidentiality are found in Regulation $17 / 62$.

57. Ivo Van Bael \& Jean-Francois Bellis, commission's second report on the application of the EC-US Agreement shows it to be a qualified success, EC Competition Law Reporter, Issue 5, 1997.

58. John Ratifif, Major Events in EC Competition Law, IBC Conference November 1995.

59. Appropriate cases may consist of, firstly, conduct having a direct, substantial and reasonably foreseeable effect on exports of goods or services from the United States, or, secondly, the US courts obtaining jurisdiction over persons or corporations engaged in such conduct.

Revista da Faculdade de Direito da UFRGS, v. 15, 1998 agreement can escape the ambit of Article 85 (1). The other means are:

Firstly, certain types of restriction in common trading arrangements are either beneficial or at least not seriously anti-com petitive. For such arrangements, the Com mission has enacted a series of block exemptions under Article 85 (3) of the Treaty. ${ }^{60}$ Unfortunately, many of these block exemptions are rigid and far from busines reality. ${ }^{61}$

Secondly, agreements may fall within Article 85 (1), but not within one of the block exemptions. Such agreements are unenforceable pursuant to Article 85 (2) rules specifically exempted by the Commis sion under Article 85 (3).

Thirdly, as already explained earlier the Commission courts have shown a tendancy towards a "rule of reason" to limit the scope of Article 85 (1). The fact and economic circumstances of each individual case must be assessed. The courts will tol erate less and less speculations by the Com mission about the market; the market must be analyzed. ${ }^{62}$

The basic rule of the doctrine of ap preciable effect, though unwritten, is that the agreement which would otherwise fall within Article 85 (1) nonetheless falls outside the prohibition where it is unlikely to affect trade between Member States or to restrict competition to any appreciable extent. This follows from the limited power principle mentioned above in conjunction with the doctrine of proportionality (see Article 36 of the Treaty).

The doctrine of appreciable effect is applied as follows: First, one must examine if the object of the agreement is to restrict, distort or prevent competition. Second, if the object of the agreement is not sufficiently detrimental to competition, the question is whether it has an appreciable effect on competition? To assess appreciability in regards to an exclusive distribution contract, one should consider the following factors: The nature of the products, the quantity to be sold under the agreement, the market position of supplier and reseller, whether the agreement is "stand alone" or part of a network, the severity of the clauses and whether parallel trade is permitted.

These guidelines necessitate defining the market. It is not likely that nonprice vertical restraints will have an anti-competitive object; thus, they will need to be assessed to establish their effect. Frequently, individual agreements will not have an appreciable effect on competition in and of themselves. These agreements therefore need to be assessed in the context of the network effect of similar agreements in the market.

In assessing "appreciability", account must also be taken of whether the arrangement under consideration belongs to a bun-

60. See e.g. Luc Gyselen, supra note 3, p. 367 et seq. for block exemptions in the field of insurance.

61. Marc van der Woude, supra. Note 3 . Also, note that the Commission is trying to move towards a more market oriented approach with its Green Paper on Vertical Restraints, infra.

62. See Delimitis above; see also Case 5/69 Völk v. Verwaecke [1969] 295, 302; a similarly rigorous trend exists in the areas of state aid; see, in particular, the very stringent ECR decision in Joined Cases C-329/93, C-62/93, C-63/95 Germany and others v Commission (Bremer Vulkan) [1996] ECR I-5151, points 23,31 and 52. 
dle of similar arrangements. In Delimitis ${ }^{63}$, the ECJ held that, while an individual agreement may not on its own appear to appreciably restrict competition, it must be examined in the context of the market in question ${ }^{64}$. It is the ease or difficulty of entry into the market by competitors, and the effect of said agreement on such entry, which determines whether the agreement has an appreciable effect. ${ }^{65}$

This theme has also been taken up in the Commission's Green Paper on Vertical Restraints. ${ }^{66}$

The Commission's Notice on Agreements of Minor Importance which do not fall within Article $85^{67}$ attempts to quantify the appreciability threshold, thus giving the term "appreciability" certainty. ${ }^{68}$ Certainty is to be achieved by introducing clear definitions: the relevant market, ${ }^{69}$ the market shares and the turnovers of the enterprises concerned. The undertakings can use this themselves as a guidance to determine whether or not their agreements fall within the scope of Article 85(1) by virtue of their minor importance. ${ }^{70}$

On October 8, 1997, the Commis sion adopted new provisions clarifying and broadening the definition of agreements of "minor importance". The turnover threshold which restricted the minor importance exemption to small and medium-sized un dertakings (SMEs) $)^{71}$ has been abolished,
63. Case C-234/89 Delimitis (1991) I ECR 935 (1992) 5 CMLR 210

64. For example, is the market concentrated, competitive or declining?

65. The Court's two-pronged test was:

Firstly, if an examination of all similar contracts entered into on the relevant market and the other factors relevant to the economic and legal context in which the contract must be examined shows that those agreements do not have the cumulative effect of denying access to that market to new national and foreign competitors, the individual agreements comprising the bundle of agreements cannot be held to restrict competition within the meaning of Article 85(1). They do not, therefore, fall under the prohibition laid down in that provision.

Secondly, if, on the other hand, such examination reveals that it is difficult to gain access to the relevant market, it is necessary to assess the extent to which the agreements entered into by the brewery in question contribute to the cumulative effect produced in that respect by the totality of the similar contracts found on that market. Under the Community rules on competition, responsibility for such an effect of closing off the market must be attributed to the breweries that make an appreciable contribution thereto. Beer supply agreements entered into by breweries whose contribution to the cumulative effect is insignificant do not therefore fall under the prohibition under Article 85(1)."

It is established that the Delimitis decision extends to all exclusive purchasing agreements. See Case C-393/92 Almelo (1994) ECR 1477. Also see, Yves Saint Laurent Partums, OJ 1992 L12/24, 31 (1993) 4 CMLR 120.

66. This analysis, titled "Green Paper on Vertical Restraints in EC Competition Policy" (hereinafter "Green Paper"), was published January 22, 1997 and is available on the DGIV website.

67. OJ $1986 \mathrm{C} 231 / 2$, amended in OJ $1994 \mathrm{C} 368 / 20$ and, lastly in OJ $1997 \mathrm{C} 29 / 3$. The Notice is for guidance only and is not binding on Community courts.

68. The Notice is based on the well-established Community principle of "appreciability" in the application of Article 85. This principle was set out most clearly in the case of Beguelin where it was stated: "in order to come within the prohibition imposed by Article 85 the agreement must affect trade between member States and the free play of the competition to an appreciable extent." See case $22 / 71$ Beguelin Import and others v. SAGL Import Export and others [1971] ECR 949.

69. Infra. Market Definition section.

70. Ibid. paragraph 3 .

71. To foster a consistent enterprise policy for SMEs a framework has been established to facilitate cooperation between small and medium sized undertakings. 1986 Notice, recital 1. The Commission acknowledges that SMEs are not generally caught by Article

Revista da Faculdade de Direito da UFRGS, v. 15, 1998 and it is now possible for agreements be tween large companies to be considered non "appreciable" as regards interstate trade and competition. ${ }^{72}$ There was no persuasive legal or economic reason for excluding larger firms holding modest market shares from the scope of the de minimis rule. This means a move away from the significance of the size of a business and towards a concentration of the economic impact of the agreement in question on competition.

The new notice will also distinguish between horizontal and vertical agreements. The market share threshold in the case of horizontal agreements will remain at the $5 \%$ level. Vertical agreements, which are ordinarily less harmful to competition, have had their threshold increased to $10 \%{ }^{73}$, thus making market penetration easier. Not to be forgotten is that one needs market definition to determine the threshold.

In cases that represent serious restrictions of competition, Article 85(1) still applies and one cannot invoke the principle of appreciable effect. This "black list" includes price fixing, production or sales quotas, and the sharing of markets or supply sources as they artificially re-erect internal borders; this would be in conflict with the internal market concept (Article $7 \mathrm{a}$ of the Treaty). The Commission will in any case take action to the extent required by Community interest, particularly in cases where the proper functions of the single market are affected.

It has been shown that the Commis sion cannot make per se decisions concerning restriction of competition. It carries the burden of initially seeking information and analyzing the market in respect of "appreciable effect".

However, two cautionary points should be emphasized:

Firstly, often the Commission goe beyond the market as it actually is ("Status quo") and tries to forecast future market developments, sometimes based on pure speculation. While recognizing that as of the time being there is no appreciable effect, the Commission may nevertheless assume a potential effect.

Secondly, unlike in German law (and perhaps other national legal orders), the Commission Notice may not even be binding on the Commission itself, but is only providing general guidance. ${ }^{74}$

5 but that the Notice does not properly address their special position in competition terms. SMEs are not completely taken outside
the scope of Article 85 . The Notice can be seen to introduce a two-level test of appreciability: a cut-off for SMEs according to the scope of Article 85 . The Notice can be seen to introduce a two-level test of appreciability:
objective criteria and an economic assessment according to factors which vary with each case.

72. Agence Europe No. 7075,9 October 1997 at 6 .

73. Ibid.

74. See, e.g. Case T-7/89 Hercules Chemicals / Kommission [1991] ECR II-1711, point 55; see also Advocate General Reischl in Case 31/80 L'Oréal v De Nieuwe Amck [1980] ECR 3775 at 3803; Advocat General Tesauro, Case C-381/87 Hoogovens Groep v. Commission [1989] ECR 3833 at 3839; question of self-binding effect of Commission communications left unresolved in Case T-353/94 Postbank NV v. Kommission id. at points 57 and 76: for an in-depth analysis see Christian Crines "Selbstbindungen der Verwaltungen im Europäischen Gemeinschaftsrecht - Eine Analyse der Rechtsprechung von EuGH und EuG zur ermessensbeschränkenden Wirkung von Gleichheitssatz und Vertrauensschutzprinzip auf Gemeinschaftebene vor rechtsvergleichendem Hintergrund", 1*t. ed. Baden-Baden (Nomos) 1997. 


\section{E. Vertical restraints}

In 1997, the Commission issued a Green Paper on Vertical Restraints in EU Competition Policy calling for comments and suggestions on improving the regulatory framework for "vertical restraints". The term "vertical agreements" describes agreements between firms that operate at different levels ${ }^{75}$ in the supply chains that bring goods and services to the market, i.e. franchise and other distribution systems in the EU. ${ }^{76}$ The Green Paper was prompted mainly by the facts that the single market legislation is now in place, and the expiration of the block exemptions for exclusive distribution, exclusive purchasing and franchising is now impending. ${ }^{77}$ The Commission also noted that a fundamental rethinking of policy was necessary in light of the importance of changed market structure.

The Green Paper must be read in the context of the EU's fundamental political objective: to integrate the countries of the EU through interpenetration of the national markets. In the pursuit of this objective, the relationship between producers and distributors, as well as other vertical relationships, have been of particular to crossborder market penetration within the Community.

In the recent landmark decisions in Metro-Cartier and Händlerbeirat, the ECJ

75. 1.e. operating either "upstream" or "downstream" of each other.

76. The European Commission's Green Paper on Vertical Restraints in EC Competition Policy was published on January 22, 1997. 77. Regulations (EEC) No. 1983/83, 1984/84, and 4260/88.

78. Case C-376/92 Metro-SB Märkte GmbH \& Co KG v. Cartier SA[1994] ECR I-15; Case C-41/96 VAG Händlerbeirat v. SYD Consult [1997]

79. Id. at point 26

80. l.e. Competition between different brands. recognized that vertical restraints could have a positive impact on market penetration. ${ }^{78}$ In Metro Cartier, the ECJ held that the lawfulness of a selective distribution system pursuant to Article 85 (1) did not (and could not) depend on the "imperviousness" of the system, i.e. a requirement developed under German law whereby the supplier can contractually prevent authorized dealers from doing business with grey market outsiders. The underlying rationale of this holding was that parallel imports were essential for market integration within the Community and therefore, as a requirement of Community law, must be hindered. The Court said that:

"... to make the validity of a selective distribution system under Article 85 (1) of the Treaty conditional on its "imperviousness" would lead to the paradoxical result that the most inflexible and most tightly sealed distribution systems would be treated more favourably under Article 85 (1) of the Treaty than distribution systems that are more flexible and more open to parallel transactions." 79

The Commission has also recognized that vertical restraints can promote efficiency, assist in penetrating a market and foster inter-brand competition, ${ }^{80}$ Nonetheless, the Commission's current policies reflect an overriding concern that vertical restraints may facilitate the partitioning of the Community market on a national basis or to exclude new entrants who would add to the competition and bring about down ward pressure on prices. ${ }^{81}$ In summary, ver tical restraints have received greater lega scrutiny in the Community than perhap in any other part of the world.

The Commission has identified fou types of distribution systems for analytica purposes: franchising, exclusive selling, ex clusive buying and selective distribution. There are specific block exemption regula tions for the first three types of distribution, and a series of Commission decisions and guidelines as well as Community court de cisions for selective distribution systems. The Commission has developed specific policies to help further the positive consequences of vertical agreements; this is the underlying rationale of the block exemp tions. ${ }^{82}$ The Green Paper recognizes that the current block exemption approach may not be satisfactory and sets out four alter native proposals for future Community policy on vertical restraints: no change from the current system, wider block exemptions, permitting greater flexibility, ${ }^{83}$ more focused exemptions that would apply only to firms with market share below a certain threshold and a reduction in the scope of Article $85(1)$, which would give rise to a rebuttable presumption of compatibility with Article 85(1) for firms with low market shares.

\section{F. In Particular: The Emergence of a Market Foreclosure Test}

The concept of market foreclosure encapsulates the Delimitis tests. ${ }^{84}$ It describes the portion of a market that is closed to competition from competitors or new entrants, on account of exclusive tying arrangements with downstream operators. Therefore, it is necessary to distinguish vertical arrangements which are essentially harmless in effect from those that must be examined under a market foreclosure..$^{85}$

81. Agreements often contain restraints which restrict the way in which the parties can buy, sell or resell goods, an example of this being exclusive purchasing provisions.

82. Please note that technology transfer block exemptions, Commission Regulation NO. 240/96, are for this reason more lenient than most other exemptions. See in general, Valentine Korah, Technology Transfer Agreements and the EC Competition Rules, passim.

83. With the exception of agreements for motor vehicle distribution, the exemption put forward would apply to the agreements between two or more undertakings that relate to the supply of goods and/or services for resale, incorporation (raw materials or ingredients) into a final "product", or consumption; and impose restrictions on the commercial freedom of one or more of the parties to the agreement. See European Competition Lawyers' Forum - Vertical Restraints Report to DGIV, September 15, 1997.

84. Supra footnote 66 .

85. A market foreclosure test can be expressed by a numeric or weighted method. A numeric test consists of calculating the number of "tied" outlets as a percentage of the total number of retail outlets in the relevant market. An alternative is the "weighting"of the volume or value of the products sold through the tied outlets and expressing them as a percenatge of the total volume or value of sales in the relevant market ("weighting test"). The tests are used in the following analytical tramework: The initial step is to consider whether the agreement has an appreciable effect on competition in its own right; if it does not, but it is part of a network of similar agreements, a numeric or weighted test must be applied to establish whether Article 85(1) may apply to the agreement given the market foreclosing effect of all other similar agreements in the market (the first Delimitis test); even if the market foreclosure test is not satisfied, the agreement in question has to be reconsidered to establish whether it, either alone or in combination with other similar agreements, makes a significant contribution to the identified market foreclosing effect (the second Delimitis test): if so, the agreement is caught by Article 85(1). 

individual agreement might not have had
Economic analysis is essential in assessing the effects of agreements, which in turn is crucial in deciding when Article 85(1) will apply to particular vertical agreements. ${ }^{86}$

The most interesting cases in the aftermath of Delimitis were Langnese and Schöller ${ }^{87}$ which dealt with networks of exclusive purchasing agreements for impulse ice-cream in Germany. The CFI held that Article 85 (1) may be inapplicable even where the market share ceiling set out in the Commission's Notice ${ }^{88}$ was exceeded. The CFI believed that it was necessary to examine the cumulative effect of the agreements and other similar agreements in their economic and legal context, as set out in Delimitis, ${ }^{89}$ in order to determine whether or not competition was affected to a significant extent. In this particular case, each a considerable anti-competitive effect but the network of agreements was found to have a substantial effect and thus all of the agreements were caught by Article 85(1).

The CFI looked at the numeric and volume weighted foreclosure effect of Schöller's and Langnese-Iglo's agreements. It stated that both the numeric and the volume weighted foreclosure effect of the two companies' agreements considered together exceeded $30 \% .{ }^{90}$ With respect to market factors, the CFI concluded that

Langnese-Iglo's and Schöller's individual networks each made a significant contribution to the foreclosure effect on the market and that Article 85(3) could not apply as the agreements did not lead to an improvement in inter-brand competition. According to the $\mathrm{CFI}$, the agreements were a major barrier to access to the market and restricted competition within the meaning of Article 85 (1).

The conclusions that can be drawn from this jurisprudence are many. The ECJ, CFI and Commission have all recognized the importance of market foreclosure tests in differentiating between situations where vertical restraints are acceptable and those where they have a harmful affect on competition. Use of the market foreclose test is evolving gradually. Additionally, it has once again been shown that in all but the clearest violations of antitrust law, it is necessary to conduct a market analysis.

\section{G. Market Definition}

There is no subject in antitrust more confusing than market definition. ${ }^{91}$ In an attempt to clear up some of the confusion, the Commission has recently prepared a Draft Notice on the Definition of the Relevant Market for the Purposes of EC Competition Law. ${ }^{92}$ The Notice is meant to apply equally to analysis conducted under Arti-

86. John Pheasant and Daniel Weston, Vertical Restraints, Foreclosure and Article 85 Developing an Analytical Framework.

87. Cases T-7/93 Langnese v. Commission [1995] ECR II-1530 and Case T-9/93 Schöller v. Commission [1995] H- 1611.

88. The Commission's Notice on Agreements of Minor Importance.

89. Cited above in footnote 3

90. See points 105 of Case T-7/93 Langnese.

91. US Healthcare Inc. v. Healthsource Inc. (986 F.2d 589). Vol. 2, issue 3, p. 45 et seq.; see further Agence Europe No. 7075 of October 9, 1997, p. 6.
92. Actual Notice expected to be available on October 28, 1997; an early draft version was published in [1997] European Counsel, cles 85 and 86, and to the Merger Regulation. ${ }^{93}$ One unquestionably needs a market definition to determine if there is an "appreciable effect" within the meaning of $\mathrm{Ar}$ ticle $85(1)$ or a "dominant position" within the meaning of Article $86^{94}$ and, if so, to determine the market share, ${ }^{95}$ to see if a merger creates or strengthens a market dominant position within the meaning of Article 2 (3) of the Merger Control Regulation, or to verify market share thresholds in block exemption regulations.

Hoping to increase transparency in the area of competition law policy and delic the procedures it follows when defining markets and the substantive criteria and evidence on which it relies when making a decision. ${ }^{96}$

The standard method of proving market power in antitrust cases requires first the defining of a relevant market in which to calculate the relevant market share. ${ }^{97}$ The relevant market within which to assess a given competition issue is established by the combination of the product/service lished simultaneously. Arguably, market cision making, the Commission makes puband geographic markets, which are estab- definition is an objective, economic conThe approach to market definition should be the same whether used under the Merger Regulation to assess market position under Article 85 to determine appreciable effect ${ }^{98}$, under Article 86 again to assess market dominance, or under block exemptions regulations to determine market share thresholds, ${ }^{99}$ with the concession that the Community courts or the Commission may assign different weight to the factors in determining market share. Up until now some Article 86 cases give the impression that markets have been defined very narrowly, to "fit" the alleged abuse. ${ }^{100}$

The most noticeable difference between the Community courts' and the Commission's manner of assessment is that the Court relies on a legal approach ${ }^{101}$, whereas the Commission prefers quantitative econometric tests. The courts have a market: The basic test is that of interchangeability of the product or service concerned from the perspective of the consumer (demand substitutability). Where there is no such demand substitutcept relying on various quantifiable factors. two-pronged test to define the relevant

93. Council Regulation of December 21, 1989 on the control of concentrations between undertakings, [1990] OJ L 257/14.

94. Here the need is less apparent as the element of appreciable effect is unwritten.

95. See Langnese.

96. Regarding the indispensability of economic analysis for market definition see Derek Ridyard "Using economies in merger control cases", [1997] European Counsel, Vol. 2, issue 3, p. 45 et seq.

97. W. M. Landes and R. A. Posner, "Market Power in Antitrust Cases", (1981) 94 Hanvard Law Review 937 at 938

98. Langnese, supra.

99. See specialization and technology transfer block exemptions.

100. James S. Venit, Market Definition: The Relevance for Artice 86 of the commission's Practice under the merger Regulation, in a speech given at the 1996 IBC EC Competition Law Conference; see the Soda Ash cases (ICl and paragraph 42 of Solvay in speech given at the 1996 IBC EC Competition Law Conference; see the
specific infra quoting Case $22 / 78$ Hugin v. Commission [1997] ECR 1869.

101. See Case 247/86, Alsatel v. Novasam, [1988] ECR 5987 and Tetra Pak Intemational v. Commission, [1996] ECR 1-5987. 
ability, the courts apply an alternative text: They then determine whether, from the viewpoint of the suppliers, these can readily switch their resources so as to produce and supply demand substitutable products (supply substitutability). ${ }^{102}$ There is a presumption that there is a sufficient degree of interchangeability between all the products forming part of the same market in so far as a specific use of such products is concerned. ${ }^{103}$ In contrast to the courts' approach, the Commission Notice takes an openly economic approach to defining the relevant market.

It should be noted that market definition may also be of importance for the legal appreciation of competitive conduct in neighbouring markets. Thus, in Tetra Pak it was found that if an undertaking has a dominant position in one market and abuses this position in a closely related market, under the Court's broad interpretation of Article 86, this is an abuse of a dominant position even in the absence of a dominant position in the neighbouring market. Tetra Pak resulted in a record 75 million ECU fine.

In defining the relevant market, one must establish the relevant market and calculate the appropriate market share. Market share tests by their very nature introduce definitional problems. Inherent in these tests is the possibility of differing interpretations between the Commission and the parties about the relevant market in which the market shares are to be measured. The Notice on Market Definition sets out a list of factors that should be taken into account in defining the relevant market, but this still leaves many issues open. It is not simply the definition of the market itself but also the calculation of the shares which is problematic. Measurement of market share creates particular problems in case of vertical agreements. For example, how should the market share of a supply agreement for components which are subsequently incorporated into other products that are offered for resale be calculated? What if the components, but not the end product, are subject to a block exemption? Is the relevant market that of the components, the finished products or both? The problem is particularly pointed for new technology.

To avoid as many problems as possible when conducting transactions relevant to Article 85 and 86 or the Merger Regulation, business persons should be advised in all the more complex antitrust matters, to have an independent market analysis done by a well-known and highly respected international market research institute.

\section{Anti-Dumping Policy}

Recently both legislation and implementation of Community anti-dumping policy have undergone important changes. ${ }^{104}$ Firstly, the CFI assumed com-

\section{2. bid. Tetra Pak.}

103. Case 85/76, Hoffmann-La Roche v Commission [1979] ECR 461, [1979] 3 CMLR 211.

104. See tor the term and the historical development of anti-dumping: Gerhard Laule, Das Europaische Anti-Dumping-Zollrecht, Entwicklung und ausgewählte Probleme, in: Die Europäische Wirtschatisgemeinschaft auf dem Weg zum einheitlichen Binnenmark und zur Steuergemeinschaft im Jahr 1992, Universität des Saarlandes, Europa InstitutVortäge, Reden und Berichte aus dem Europa-InstitutiNr: 146 (Georg Ress, Michael R. Will, ed. 1988), p. 47 et seq.

Revista da Faculdade de Direito da UFRGS, v. 15, 1998 petence for applications for the annulment of regulations and decisions in the field of anti-dumping. ${ }^{105}$ Secondly, the "New AntiDumping Regulation"106 was adopted. A third development, which has brought about important changes, is the GATT Panel Report focusing on a dispute settlement procedure brought by Japan against a definitive anti-dumping duty imposed by the European Council on Japanese origin audiocassettes. ${ }^{107}$

\section{A. Overview of CFI's \\ Jurisprudence since being \\ awarded Jurisdiction over \\ Anti-dumping Matters}

NTN Corporation and Koyo Seiko Co Ltd. v. Council ${ }^{108}$ was the first anti-dumping case to be decided under the CFI's new jurisdiction over anti-dumping matters. It concerned an appeal by two Japanese firms against a European regulation imposing definitive anti-dumping duties on ball bearings larger than $30 \mathrm{~mm}$ from Japan. ${ }^{109}$ To the satisfaction of all but the European institutions, it heralded a new era in Euro-

105. As of March 15, 1994, the CFI assumed comperis

As or March 15, 1994, the CFl assumed competence for applications for the annulment of regulations and decisions in the field of anti-dumping, pursuant to Council Decision No. 94/149/ECSC, EC of 7 of March 1994 amending Decision 93/350/Euratom, ECSC, EEC amending Decision 88/591/ECSC, EEC, Euratom establishing a Court of First Instance of the European Communities, OJ 1994, L 66/29.

106. Council Regulation No. 3283/94 of 22 December 1994, OJ $1994 \mathrm{~L} 349 / 1$; as subsequently amended in Council Regulation No. $355 / 95$ of 20 February 1995, OJ 1995 L 41/2, and in Council Regulation No. 1251/95 of 29 May 1995, OJ 1995 L 122/1.

107. Council Regulation No. 1251/91 of 13 May 1991, OJ 1991 L 119/35, C-177/87 Sanyo Electric v Council [1992] I - 1535; C-69/89 Nahojima All Precisions v Council, [1995] II-1381.

108. Joined Cases T-163 and 165/94, NTN Corporation and Koyo Seiko Co. Ltd. v. Council, [1995] ECR II-1381.

109. Council Regulation (EEC) No 2849/92 of September 1992 modifying the definitive anti-dumping duty on ball bearings with a greatest external diameter of $30 \mathrm{~mm}$ originating in Japan imposed by Regulation (EEC) No 1735/85, OJ L 286/1.

110. This approach is precisely in line with the CFI's paper on aspects of the Maastricht Treaty in which it supports an independent judiciary. See Rapport de la Cour de Justice sur Certains Aspects de l'Application du Traité sur 'Union Européenne, Luxembourg, May 1995.

111. Agreement on Implementation of Article VI of the General Agreement of Tariffs and Trade 1994 in Annex 1 A to the Marrakesh Agreement Establishing the World Trade Organization. pean jurisprudence in the field of anti-

The approach of the CFI is that of factual approach. 110 This was seen as a refreshing change to the Commission's and Council's habit of permitting external pothe le-

The ECJ traditionally had limited itself to a superficial examination of whether ably come to the challenged decision. The traditional grounds for annulment, if any,

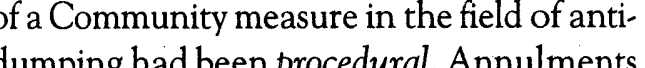
systematically refrains from y the Community institutions.

The CFI so far has gone much further. It concentrates on the facts and relies ATT Anti-dumping Code. Thus, for example, in NTN, the CFI relied

Revista da Faculdade de Direito da UFRGS, v. 15, 1998 
dence requirements and, on that basis, emphasized that a threat of injury must be based on facts and not merely on possibilities, conjecture or allegations. ${ }^{112}$ The CFI meticulously conducted a fully-fledged substantive review of the facts and mercilessly branded the Commission's superficial analysis thereof by quashing the Commission's decision.

Such a painstaking factual review of an institution's findings in the field of antidumping had been notably absent from the ECJ's rulings. ${ }^{113}$ Its introduction into Community jurisprudence means greater legal guarantees in anti-dumping proceedings. At the same time, the intensification of judicial review has a deterring effect on the Commission and on the Council. Since NTN, business persons involved in antidumping matters should be encouraged more than before to produce as much economic evidence on point as possible and to refine their methods of presentation to the Commission of such evidence.

A further change was the CFI's application of the GATT Anti-Dumping Code. This could mean an increased reliance by the CFI on GATT law.

\section{GATT Anti-dumping Code Article 3(7)}

113. The ECJ has tended away from such an approach, favouring to make decisions on clear-cut procedural and other legal issues. See for example Case C-104/90 Matsushita Electric Industrial v. Council [1993] ECR 1-4981, and Case C-216/91 Rima Electrometalurgia v. Council[1991] ECR I-6303.

114. Id. at points 119 to 125. The Council had argued that in Case C-121/86 Kai Naftiliakon v. Council[1989] ECRI-3919, and the Court had not objected to a delay of four years. The CFI stated that the one-year time limit for completing an investigation in an antihad not objecled to a delay of four years. The CFtiation must not extend beyond a reasonable period, which is to be determined dumping procedure is only a guideline. The investigatlon must not exlend beyond a easonable period, which is to be determined in light of individual circumstances. In the NTN \& Seiko cases the market was one the Community institutions knew well and the last review of it had been completed in ten months. See Article 7 (9) (a) of Regulation No. 2423/88 (the basic anti-dumping regulation).

115. Case 162/94 NMB France and others v. Commission [1996] ECR II-427; C-156/87 Gestetner Holding v Council and Commission [1990] 1-781; C-133/87, C-150/87 Nashua v Commission [1990] 1-719.

116. Case 280/93 Germany v Council [1994] ECR 1-4973, point 94.

Revista da Faculdade de Direito da UFRGS, v. 15, 1998 required to pursue ${ }^{117} \cdot{ }^{118}$ It must be emphasized, however, that the applicants have failed to describe the effects the decision in question would have had on their economic and financial situation. The applicants submitted the question of the legality of the measure taken rule for review without contesting the various calculation methods and figures arrived at by the Commission. The CFI found that it was therefore not in the position to assess, as part of the judicial review, the real economic impact of the contested measure. Thus the Court's review was limited to considering only a question of law which the applicants had themselves separated from the economic context of the case.

Therefore, in spite of the NMB case it is certain that, since the CFI has had jurisdiction over anti-dumping matters, the standard of review has been stricter. It is the complainant's duty to make certain that the CFI receives the opportunity to conduct its rigorous analysis.

\section{B. The "New" Anti-Dumping Regulation}

The "new" anti-dumping regulation is nothing revolutionary and addresses recurrent problems. Three of these problems having arisen in recent jurisprudence are of strong relevance to international business: individual treatment in case of exports from non-market economics, anti-circumvention measures, and references to third countries in case of non-market economics.

\section{International Treatment}

Granting individual treatment to exporters from non-market economies (NMEs) means that the dumping margin is sought to be determined on a case-by-case basis and that, where appropriate and possible, the anti-dumping duty is fixed for each exporter individually. This topic of individual treatment is again of widespread interest in light of the imposition anti-dumping duties on exports from the People's Republic of China ${ }^{119}$ and the great extent of foreign manufacturing investment into China and Vietnam. The Commission usually imposes a uniform anti-dumping duty on all exports originating in NMEs on a country-by-country basis. Regarding State-trading countries, the Commission generally determines one global weighted average anti-dumping duty for all exporters without regard to their individual circumstances and uses a third country market economy as the basis to calculate the "normal value", i.e., in non-legal terms, the domestic price of the product concerned. The underlying policy is based on the assumption that exporters in State-trading countries are not independent from state

117. Id. at points 69 and 70 .

118. The basic anti-dumping regulation was adopted by the Council as part of the common commercial policy which was characterized by a wide discretion in its implementation which necessarily extended to the adoption and implementation of the basis regulation. by a wide discretion in its implementation which necessarly extended to the adoption and implementation of the basis regulation.
This latitude enjoyed by the legislature corresponds to that which the institutions had when adopting specific anti-dumping measThis latitude enjoyed by the legislature corresp
ures pursuant to the basic regulation. Ibid.

119. See, e.g. Footwear from China and Indonesia, Regulation $165 / 97$ (1997) OJ L 29/3; Handbags from China, Regulation 209/97 (1997) OJ L 33/11; Ring Binder Mechanisms from China, Regulation 119/97 (1997) OJ L 22/1. 
influence. The objective is to avoid circum venting anti-dumping on exports from nonmarket economies duties by routing exports through an exporter within that economy who was granted a lower anti-dumping duty. ${ }^{120}$

There had been cases in the early 1990s where company-specific anti-dump ing duties were imposed under the "individual treatment" policy. Recently, in the foundation laying cases of Small Screen $T V s^{121}$ and Bicycles, ${ }^{122}$ the exporters from State-trading countries in vain tried to satisfy the Commission that state influence was minimal and that the companies' export policy was exercised autonomously.

Individual treatment is a legitimate policy. ${ }^{123}$ It should be granted in order to avoid unjustifiable interference with the rights of companies who in their business activities are independent from the Statetrading country. ${ }^{124}$ A working paper rethinking the approach to individual treatment has been circulated to the Member States. It proposes a more flexible and fairer approach and is endorsed by Sir Leon Brittan, Vice President of the Commission, who wants to rationalize anti-dumping

procedures so that they take account of the commercial interests of the EC. ${ }^{125}$

The WTO rules (Article VI of GATT 1994 and the Anti-Dumping Code) allow importing countries wide discretion in applying anti-dumping duties to NMEs. Legally, the Community's methods seem difficult to challenge. It should be noted, however, that Community law and practice are more stringent than the law and practice of other countries. For example, it appears that several countries are now treating China as a market economy.

\section{Anti-circumvention Measures}

A recurrent problem in anti-dumping anti-circumvention and standing of private companies pursuant to Article 173 (5) of the EC Treaty to challenge anti-circumvention measures before the Community courts.

This is illustrated in the Sinochem case. ${ }^{126}$ As soon as the Community institutions realize that exporters may have such standing, this enhances the influence of the exporters before the institutions, for example in regard to access to the Commission's

120. See Case T-161/94 Sinochem Heilongjiang v. Council [1996] ECR II-695.

121. Small Screen Televisions, Regulation 2093/91 OJ 1991 L 195/1 (Definitive Duties).

122. Regulation 2474/93 OJ L 228/1, upheld in a Judgment of the CFI of September 25, 1997, Case T-170/94 Sahnghai Bicycle Corporation (Group) v. Counci, not yet officially published.

123. See Council Regulation No. 384/96 on the protection against dumped imports from countries not member of the European Community: OJ 1996 №. L 56, p. 1; amended by Council Regulation No. 2331/96 of December 2, 1996, OJ 1996 №. L 317, p. 1.

124. See Michael Sánchez Rydelski, Individual Treatment in EC Anti-dumping Cases Concerning State-trading Countries, (1997) EuZW Europäische Zeitschritt für Wirtschaftsrecht 138. The criteria defining a company as independent from a State-trading country as set out in recent decisions is as follows. The company must show that it is: Owned in the majority by a foreign investor, a profit oriented entity, freely able to transfer profits outside of the State-trading country, independent in running its business and able to set its export prices autonomously.

125. See Sánchez Rydelsky id. at preceding footnote quoting the Financial Times of 1 October 1996, page 5

126. Case T-161/94, Sinochem Heilongjiang v. Council (1996); C-171/87 Canon v Council [1996] ECR II-695. file. In Sinochem, the CFI recognized the standing of the Chinese producers and exporters. The Commission had argued in vain that applications for annulment of antidumping regulations lodged by individual companies operating in China, a NME, are inadmissible because the applicants are not individually concerned. The institutions had further argued that only the Chinese State or a state organization in charge of products has standing to request the annulment of an anti-dumping regulation imposing duties. The CFI relied on the Sinochem's participation in the administrative investigation and particularly on the fact that the Commission treated the applicants as any other participant in the investigation. typewriter case, ${ }^{127}$ best illustrates the importance of the rules of origin, to the extent that the origin of a product is not solely determined by the place from where it is exported. Brother assembled typewriters in Taiwan and exported them to the Community stating that they were of Taiwanese origin. The Commission found them to be of Japanese origin and subjected them to the duty imposed on Japanese typewriters. Goods have the origin of the country where the "last, substantial, economically justified processing or working" was carried out. ${ }^{128}$ the vast majority of exports of the relevan

Another case, the Japanese Brother

The Court held in Brother that even mere assembly of parts from third countries could confer the origin of the country in which assembly takes place "provided that from a technical point of view such assembly represents the decisive production stage during which the use to which the component parts are to be put becomes definite and the goods in question are given their specific qualities." Provided that the technical test is inconclusive, one can look at value added to see if "the assembly operations in question result in an appreciable increase in the commercial, ex-factory value of the finished product." No concrete level of value added determining origin was given, but the Court did indicate that $10 \%$ was inadequate.

The Community's "new" anti-circumvention rules allow the Community to impose anti-dumping duties on products or parts used to make products imported into the Community whenever these products are found to be circumventing anti-dumping duties which the EU had previously imposed on like products. The most significant change in the Community's basic anti-dumping regulation ${ }^{129}$ deals with the extension of these anti-circumvention powers to cover assembly operations in third countries. This is of particular interest to Japanese companies with plants in SouthEast Asia, due to the value of the yen and

127. Case C-26/88, Brother International GmbH v. Hauptzollamt Giessen [1989] ECR 4253. See also: Gerhard Laule, supra footnote 105, p. 58 et seq.

128. Article 24 of the Community's Customs Code; see also Council Regulation No. 2913/92 of 12 October 1992 which states: "Goods whose production involved more than one country shall be deemed to originate in the country where they underwent their last, substantial, economically justified processing or working in an undertaking equiped for that purpose and resulting in the manufacture of a new product or representing an important stage of manufacture."

129. See Article 13 (2) of that regulation. 
because of anti-dumping duties against direct exports to the Community of certain products of Japanese origin. ${ }^{130}$

In light of this modification, assembly plants in third countries, South-East Asia for instance, could find themselves subject to as many as three types of investigation: a new anti-dumping case against products of that third country origin, an origin investigation to see if those products are really of Japanese origin, and/or an anticircumvention investigation under the Anti-dumping Regulation.

Judicious advice for companies with third-country assembly plants is to make certain that the products manufactured in such facilities definitely have the origin of the country in which they are being assembled so that the conditions for the application of the anti-dumping circumvention rules are not satisfied. While countries such as China and Vietnam have such low labor costs, the test for origin would/should be the technical one. Thus, local origin could be obtained due to the complexity of the local manufacturing process without the local value added amounting to a substantial percentage of the manufacturing cost.

\section{Third Country References}

The extremely recent decision in Rotexchemie discusses the issue of reference countries, which are necessary when dealing with determining normal value or in-

\section{Please note that these provisions are not relevant if there are no anti-dumping duties in the first place. They are relevant where anti-dumping duties are imposed against countries other than Japan. For example, however, a Japanese company could have a subsidiary in Taiwan whose exports to the Community were subject to an anti-dumping duty and the anti-circumvention rules could be applied to another plant in, for instance, China.}

131. Judgment of the ECJ of May 29, 1997 Case C-26/96 Rotexchemie International Handels GmbH \& Co., not yet officially published. 132. See, the GATT Panel Report on Audio Cassettes.

Revista da Faculdade de Direito da UFRGS, v. 15, 1998 jury in conjunction with a NME. It is noted that the Community institutions have wide discretion in choosing a reference country, but that the Court is to verify whether the relevant procedural rules were complied with, whether the facts on which the choice was based were accurately stated and whether there was a manifest error of ap. praisal or a misuse of powers. ${ }^{131}$ The Council and Commission are not required to consider every country proposed by the parties during an anti-dumping proceeding, but they are required to examine in greater depth the proposals submitted to them if they ought to have doubts concerning their choice of countries.

\section{Japanese Origin \\ Audiocassettes}

In 1995, a GATT Panel, established at the request of Japan, ruled that the definitive anti-dumping duty imposed by the Council on Japanese origin audio cassettes was in violation of the 1979 Anti-dumping Code. The controversy involved the determination by the Commission of the domestic sales value at an extremely low level in the distribution chain when sales are made through related parties, while export prices were established at higher levels. Japan claimed that adjustments should have been made to render the comparison between the domestic sales price and the export price fair. ${ }^{132}$
The Panel found that indirect costs could affect prices and held it unfair of the EC to deduct certain costs and profit in constructing the export price, but leaving similar expenses and profit in the normal value. ${ }^{133}$ The Panel examined whether the price in one market was based on a price charged by a seller who performed additional functions entailing additional investments and costs. The Panel decided that the comparability of the prices could be affected, and that it might be necessary to make allowance in the form of an amoun for profits related to the additional functions performed. The Panel concluded that Article 2(9) and 2(10) of the Commissions former Basic Regulation were inconsistent with Article 2:6 of GATT as they precluded the making of justified allowances for dif ferences in indirect selling expenses and with respect to profits related to a difference in the function performed by the seller in the domestic and export markets, a difference that could affect price comparabil ity. ${ }^{134}$ As the Commission normally took the sale of the first independent customer as the starting point, the Panel found it necessary to make a distinction between related and unrelated steps in the distribution channel. ${ }^{135}$

The GATT report ${ }^{136}$ partially agreed with Japan and recommended that the $\mathrm{EC}$ be required to reconsider its determination in this investigation and to bring its legislation into conformity with GATT. On the basis of the pre-WTO dispute settlement rules, the Community did not adopt the GATT report. ${ }^{137}$

\section{Conclusion}

It has been shown that there are several elements of uncertainty for foreign business strategies in the fields of antitrust and anti-dumping under European Community Law. These elements of uncertainty are rooted in the strained relationship between a more factual and a more abstract, i.e. more political, approach. Although there are positive signs for a more factual approach, foreign business persons always have to be aware of this strainend relationship when dealing with antitrust oder anti-dumping matters.
133. GATT Panel Report on Audio Cassettes paragraphs 370.372. Also see, Electronic weighing scales from Japan, OJ L 104/7 (1993) and B. Hindley, Dumping and the Far East Trade of the European Community, 11 World Economy, 1988, 445; E. Vermulst, The Anti-Dumping Systems of Australia, Canada, the EEC and the USA - Have Anti-Dumping Laws become a Problem in International Trade? In J.H. Jackson and E.A. Vermulst (eds.), Anti-Dumping Law and Practice- A Comparative Study, University of Michigan Press, Ann Arbor, Michigan, 1989, at 451; P. Waer, Constructed Normal Values in EC Dumping Margin Calculations - Fiction, or a Realistic Approach? 27 J.W.T. 4 August 1993, 47, at 53.

134. Ibid. at $113-114$.

135. Ibid. at 114. A Typical distribution channel is as follows: producer $₫$ distributor $(\circledR$ wholesaler $\circledast$ dealer $₫$ end-user. 136. EC Anti-dumping duties on audio tapes in cassettes originating in Japan, ADP 136, unadopted, 28 April 1995.

137. Edwin Vermulst and Bart Driessen, Commercial Defense Actions and Other International Trade Developments XII: 1 July 1996 31 December 1996, European Journal of International Law 1997 at 363. 